\title{
Monocytic leukemia zinc finger protein is essential for the development of long-term reconstituting hematopoietic stem cells
}

\author{
Tim Thomas, ${ }^{1}$ Lynn M. Corcoran, Raffi Gugasyan, Mathew P. Dixon, Thomas Brodnicki, \\ Stephen L. Nutt, Donald Metcalf, and Anne K. Voss ${ }^{2}$ \\ The Walter and Eliza Hall Institute of Medical Research, Parkville, Victoria 3050, Australia
}

\begin{abstract}
Monocytic leukemia zinc finger protein (MOZ), a transcriptional coactivator and member of the MYST family of histone acetyltransferases, is the target of recurrent translocations in acute myeloid leukemia. Since genes associated with translocations in leukemia are typically important regulators of blood formation, we investigated if Moz has a role in normal hematopoiesis. We generated mice carrying a mutation in the $\mathrm{Moz}$ gene. Homozygous Moz mutant mice died at birth. Moz mutant fetal liver hematopoietic cells were incapable of contributing to the hematopoietic system of recipients after transplantation. We observed profound defects in the stem cell compartment of Moz-deficient mice. Progenitors of all lineages were reduced in number. However, blood cell lineage commitment was unaffected. Together, these results show that Moz is essential for a fundamental property of hematopoietic stem cells, the ability to reconstitute the hematopoietic system of a recipient after transplantation and that Moz is specifically required in the stem cell compartment.
\end{abstract}

[Keywords: Monocytic leukemia zinc finger protein; histone acetyltransferase; hematopoiesis; stem cells]

Supplemental material is available at http://www.genesdev.org.

Received October 7, 2005; revised version accepted February 24, 2006.

\section{Introduction}

Moz is a MYST family coactivator with histone acetyltransferase activity (Yang 2004). Transcriptional coactivators form multiprotein complexes that are recruited to specific genomic loci by DNA-binding transcription factors. Coactivator complexes typically contain an enzyme subunit with chromatin-modifying activity, such as a histone acetyltransferase (Berger 2002). It has been suggested that the exchange of a corepressor complex with a coactivator complex, containing a histone acetyltransferase, may be a critical element in promoting gene expression (Glass and Rosenfeld 2000). Rather than forming a passive link between DNA-binding transcription factors and the basal transcriptional apparatus there is increasing evidence that coregulator complexes provide an additional level of regulation where gene expression patterns and consequently cellular phenotype are determined (Taatjes et al. 2004). Considerable progress has been made in identifying the DNA-binding transcription factors that direct the differentiation of specific blood

Corresponding authors.

${ }^{1}$ E-MAIL tthomas@wehi.edu.au; FAX 61-3-9347-0852.

${ }^{2}$ E-MAIL avoss@wehi.edu.au; FAX 61-3-9347-0852.

Article and publication are at http://www.genesdev.org/cgi/doi/10.1101/ gad.1382606. lineages (Zhu and Emerson 2002). Nevertheless, it is not clear how these transcription factors direct gene expression and hence the differentiation of diverse lineages. Paradoxically, a transcription factor may have several distinct functions in the differentiation of a single cell lineage (Zhu and Emerson 2002) as well as additional functions in completely different cell types. In addition, a DNA-binding transcription factor-for example, a nuclear receptor-may act under some conditions as a repressor, while under different conditions it might promote transcription (Glass and Rosenfeld 2000). Studies of the nuclear receptors suggest that the nature of the available coregulatory complexes plays an important role in determining the range of activity of DNA-binding transcription factors (Glass and Rosenfeld 2000). Since all developmental processes ultimately depend on precise regulation of transcription, identification of the coactivators involved is a necessary step in understanding the genetic regulation of development. We have previously shown that another member of the MYST family, Querkopf, is required for telencephalon and bone development (Thomas et al. 2000). Querkopf has an identical domain structure to $\mathrm{Moz}$, and all functional domains are highly conserved (Thomas and Voss 2004).

The acetylation status of histones is determined by the opposing action of histone acetyltransferases and histone 
deacetylases (Strahl and Allis 2000). Deregulation of histone acetylation is involved in the pathogenesis of acute myeloid leukemia. The translocation $\mathrm{t}(8 ; 21)$ causes the expression of a AML1-ETO fusion protein that leads to acute myeloid leukemia. It has been shown that this fusion protein associates with a histone deacetylase complex that represses AML1 target genes and blocks differentiation (Gelmetti et al. 1998; Lin et al. 1998; Lutterbach et al. 1998; Wang et al. 1998). The recruitment of histone deacetylases appears to be a significant factor in the pathology of a least some types of leukemia since it has been shown that inhibitors of histone deacetylase can promote differentiation of primary blast cells from acute myeloid leukemia patients (Ferrara et al. 2001). In addition, a histone deacetylase has been shown to associate with the Retinoic acid receptor $\alpha$ fusion proteins found in acute promyelocytic leukemia and block transcription (Grignani et al. 1998; Guidez et al. 1998; He et al. 1998) and histone deacetylase inhibitors in combination with other agents, have been shown to be effective in the treatment of acute promyelocytic leukemia (Redner et al. 1999|. Together these reports show that disruption of the regulation of gene expression mediated by the deacetylation of histones is important in the pathogenesis of leukemia and suggests that proteins regulating chromatin structure, through acetylation of histones, have an essential role in normal hematopoiesis.

MOZ was originally identified in a recurrent chromosomal translocation $\mathrm{t}(8 ; 16)(\mathrm{p} 11 ; \mathrm{p} 13)$ associated with acute myeloid leukemia (Borrow et al. 1996). This translocation defines a distinct subtype of M4/M5 acute myeloid leukemia. The prognosis of patients with this translocation is poor (Stark et al. 1995). The $\mathrm{t}(8 ; 16)(\mathrm{p} 11 ; \mathrm{p} 13)$ translocation results in the in-frame fusion of the $M O Z$ gene with the $C B P$ gene. The resulting fusion protein consists of MOZ, without the C-terminal domains, fused to almost all of CBP, another coactivator of transcription. Other recurrent chromosomal rearrangements found in acute myeloid leukemia lead to the fusion of MOZ with the CBP-like coactivator, p300 (Chaffanet et al. 2000; Kitabayashi et al. 2001b). A case of myelodysplastic syndrome has been reported in which MOZ is fused to an uncharacterized gene (Imamura et al. 2003). In addition to translocations involving CBP or the closely related protein p300, other recurrent chromosomal rearrangements leading to leukemia result from the fusion of MOZ with the nuclear receptor coactivator, TIF2 (Carapeti et al. 1998; Liang et al. 1998). These fusion proteins also lack the C-terminal domains of MOZ. Studies of the MOZ-TIF2 fusion have shown that this protein is able to induce long-term self-renewal in committed myeloid progenitors and so initiate leukemic stem cell proliferation (Huntly et al. 2004).

Recently it has been reported that MOZ can interact with AML1 in vitro (Kitabayashi et al. 2001a). Chromosomal rearrangements of the $A M L 1$ (RUNX1) gene are the most common chromosomal rearrangements associated with leukemia (Downing et al. 2000). AML1 is required for the establishment of definitive hematopoiesis (Okuda et al. 1996; Wang et al. 1996), and has a role in both megakaryocyte and T-cell differentiation (Ichikawa et al. 2004). AML1 has been shown to bind to MOZ in vitro suggesting that $\mathrm{MOZ}$ may act as a coactivator for AML1. An interaction with AML1 takes place through the C-terminal serine- and methionine-rich domains of MOZ. These are domains unique to MOZ and the very similar protein, Querkopf (Thomas et al. 2000). Binding of MOZ stimulates AML1-mediated transcription and the removal of these domains prevents MOZ activation of AML1 in vitro (Kitabayashi et al. 2001a).

Zebra fish (Danio rerio) carrying mutations in the $\mathrm{Moz}$ gene have been isolated in an ENU screen for fish exhibiting cartilage defects. The Moz mutant fish show pharyngeal segment identity defects (Miller et al. 2004). However the role of Moz in zebra fish hematopoiesis was not addressed.

To determine the physiological role of Moz during mammalian development we studied the effect of mutating the Moz gene. Since genes affected in recurrent chromosomal translocations leading to leukemia are likely to be critical regulators of blood formation (Orkin 2000), we concentrated this analysis of the Moz mutant mice on the development of the hematopoietic system.

\section{Results}

The Moz ${ }^{\Delta}$ mutation causes perinatal lethality

We created a truncation of the mouse $M o z$ gene $\left(M o z^{\Delta}\right)$ by the in frame insertion of the neomycin phosphotransferase (neo) coding sequence into exon 16. The insertion site is in an equivalent position to the $t(8 ; 16)$ breakpoint found in human leukemia and results in the deletion of the C-terminal domains of Moz (Fig. 1A-E). The truncation of the Moz coding sequence in these mice occurs in a similar position to the truncation resulting from a point mutation in the less severe of two ENU generated mutant zebra fish Moz alleles (Miller et al. 2004). We deleted the C-terminal domains of Moz, because a common feature of translocations involving the $M O Z$ gene is that these domains are absent in the fusion protein as well as being shown, in vitro, to mediate protein-protein interactions. However, no protein product of the mutant locus could be detected in homozygous embryos by Western analysis even though mRNA was produced at normal levels (Fig. 1E,F; Supplementary Fig. 1). In addition, no mutant protein could be detected in the thymus, lung, kidney or bone marrow (tissues in which Moz is strongly expressed) of heterozygous adult animals. In these experiments the $\beta$-galactosidase-neo fusion protein produced by a gene trap allele of $\mathrm{Qkf}$ (Voss et al. 1998; Thomas et al. 2000; Thomas and Voss 2004) was used as a positive control. Since $1 a c Z-n e o$ fusion mRNA is expressed less strongly than the Moz mutant mRNA (Supplementary Fig. 1), and a corresponding $\beta$-galactosidase-neo protein could easily be detected, this suggests that the protein produced from the $M o z^{\Delta}$ allele may be unstable or inefficiently translated.

Homozygous $\mathrm{Moz}^{\Delta / \Delta}$ mice died at birth. Although not anemic, they failed to oxygenate their blood (Fig. 2E,F), 
A
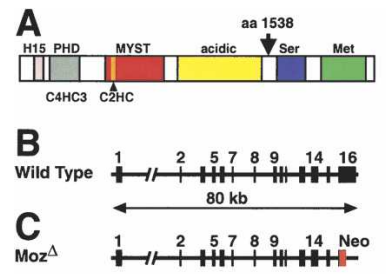

D

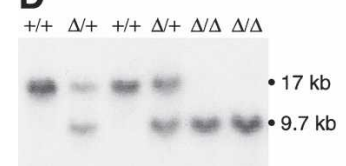

E

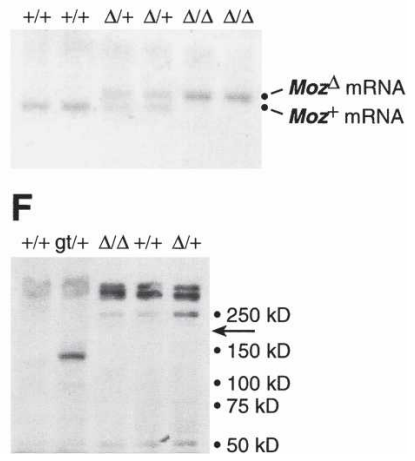

Figure 1. The $M o z^{\Delta}$ mutation. (A) Domain structure of Moz. (H15) H15 domain; (PHD) PHD zinc finger domain (C4HC3); (MYST) MYST histone acetyltransferase domain, the nucleosome-binding motif $(\mathrm{C} 2 \mathrm{HC})$ is indicated by a bar (arrowhead) within this domain; (Acidic) acidic domain; (Ser) serine-rich domain; (Met) methionine-rich domain. An arrow indicates where truncation of Moz protein was generated at amino acid 1538 by the in-frame insertion of the neo gene in the mutant allele. $(B)$ Wild-type $M o z$ allele showing 16 coding exons distributed over $80 \mathrm{~kb}$. The C-terminal domains are encoded entirely by exon 16 . (C) Mutant $M o z^{\Delta}$ allele after homologous recombination showing the insertion site of neo. (D) Southern analysis of BglIIdigested genomic DNA showing the predicted fragment-length polymorphism after hybridization with a probe outside of the targeting construct, wild-type $(+/+)$, heterozygous $(\Delta /+)$, and homozygous mutant $(\Delta / \Delta)$ genomic DNA. $(E)$ Northern analysis of $\mathrm{Moz}^{\Delta / \Delta}, \mathrm{Moz}^{\Delta /+}$, and $\mathrm{Moz}^{+/+}$littermate embryos at E13.5; note that the insertion of the neo coding sequences cause an increase mRNA of $1 \mathrm{~kb} .(F)$ Western analysis of $\mathrm{Moz}^{\Delta / \Delta}, \mathrm{Moz}^{\Delta /+}$, and $\mathrm{Moz}^{+/+}$littermate embryos using an antibody against neo. Note that no band corresponding to the Moz-neo fusion protein is detectable at the predicted size of $204 \mathrm{kD}$ (indicated by arrow) in the $\Delta / \Delta$ or $\Delta /+$ lanes. In contrast, the two control lanes at the left show detection of the $\beta$-galactosidase-neo fusion protein (145 $\mathrm{kD})$ produced in the cortex of $\mathrm{Qkfgt}(\mathrm{gt} /+)$ mice but not present in the cortex of a wild-type littermate $(+/+)$. Filter was exposed for $1 \mathrm{~h}$. Note that bands $\geq 50 \mathrm{kD}$ are the result of nonspecific binding.

probably as a result of aortic arch defects, and exhibited facial abnormalities, including a cleft palate (data not shown). Craniofacial defects are also observed in zebra fish carrying mutations in the Moz gene and in both species similar structures are affected (Miller et al. 2004). At day 18.5 of gestation (embryonic day 18.5 [E18.5]) homozygous $\mathrm{Moz}^{\Delta / \Delta}$ fetuses had severe dysgenesis of both the thymus and spleen (Fig. 2G-N). While the $M o z^{\Delta / \Delta}$ pups are of normal size, the thymic lobes of the mutant animals were approximately one-fourth the size of wildtype fetuses (Fig. 2C,D) and frequently only one lobe descended. Early in development the spleen anlage was indistinguishable between mutant and littermate control animals. However, there was a failure of the spleen to develop such that by E18.5 the site of spleen in the mutant animals could only be identified by the presence of a poorly developed blood vessel network within the mesentery (Fig. 2E,F). Histologically the mutant thymus appeared poorly organized, lacking a clear medulla. Ec-

topic cystic structures, probably of thymic origin, were observed (Fig. 2G,H). There were instances of minor bleeding associated with the thymus. The spleen in the mutant animals appeared as a slightly thickened region of mesentery in transverse sections (Fig. 2I,J). The E18.5 mutant animals had a normal hematocrit and all leukocyte lineages were present (Supplementary Fig. 2), although a slight, but statistically significant, elevation in the levels of nucleated red blood cells was observed in the mutants (Table 1). Maturation of erythrocytes was studied by flow cytometry and showed that differentiation from CD71 $1^{\text {high }}$ Ter119 low through to Ter119 high CD71 ${ }^{\text {low }}$ proceeded normally with the exception that the $\mathrm{CD} 71^{\text {high }}$ Ter119 ${ }^{\text {high }}$ population in the mutant fetal liver was larger than in the wild type (Supplementary Fig. 3). This shows that erythroid cell maturation oc-
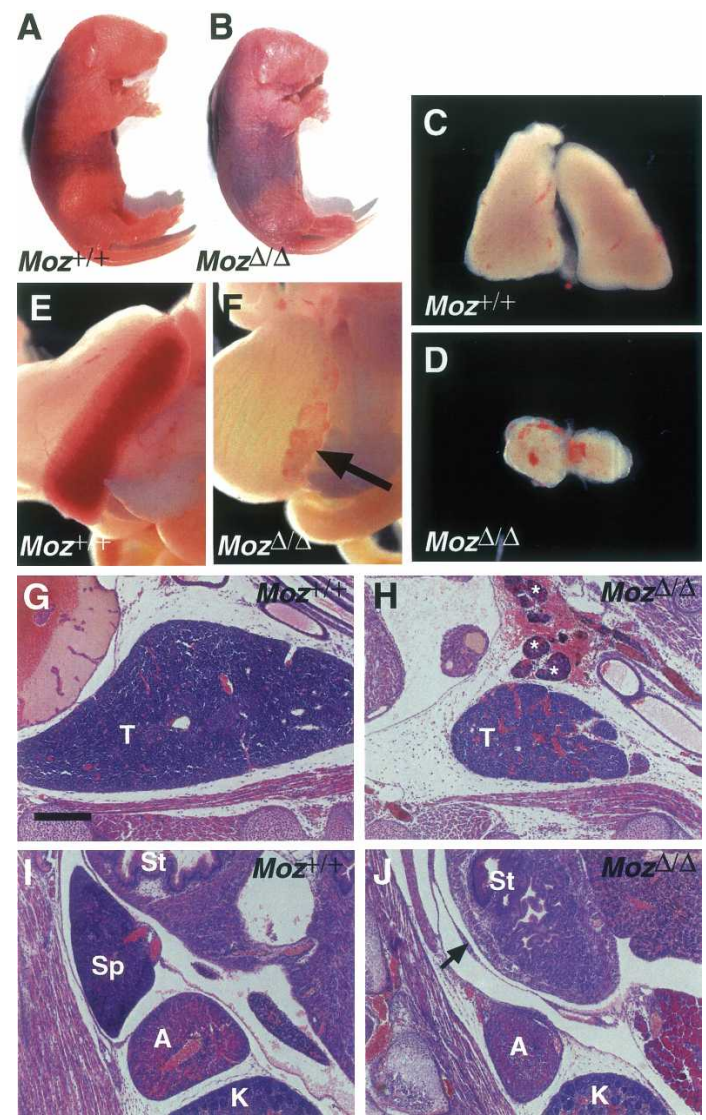

Figure 2. The $M o z^{\Delta / \Delta}$ phenotype. Wild-type littermate $(A)$ and homozygous $(B) \mathrm{Moz}^{\Delta / \Delta}$ E18.5 pup of a $\mathrm{Moz}^{\Delta /+}$ heterozygous intercross. Note that the homozygous $\mathrm{Moz}^{\Delta / \Delta}$ pup is cyanotic, indicating a lack of oxygenated blood ( $n=32$ E18.5 pups). Wildtype thymus $(C)$ compared with $M_{o z}{ }^{\Delta / \Delta}$ thymus $(D)$ at E18.5. Wild-type spleen $(E)$ compared with mutant spleen (arrow, $F$ ) at E18.5. Hematoxylin and eosin-stained transverse sections of E17.5 fetuses showing wild-type $(G, I)$ and $M o z^{\Delta / \Delta}$ littermate $(H, J)$. Note dysgenic thymus $(D, H)$ and dysgenic spleen $(F, J)$ in mutant animals. $(H)$ Minor bleeding and cystic remnants, probably of thymic origin (asterix). ( $J$ ) The largest extent of the $\mathrm{Moz}^{\Delta / \Delta}$ spleen is shown (arrow). (A) Adrenal gland; (K) kidney; (Sp) spleen; (St) stomach; (T) thymus. Bar: $G-I, 310 \mu \mathrm{m}$. 
Table 1. Percent frequency blood cell count E18.5

\begin{tabular}{lrrc}
\hline Cell type & \multicolumn{1}{c}{$\mathrm{Moz}^{+/+}$} & \multicolumn{1}{c}{$\mathrm{Moz}^{\Delta /+}$} & \multicolumn{1}{c}{$\mathrm{Moz}^{\Delta / \Delta}$} \\
\hline Blast cells & $2.2 \pm 1.0$ & $1.9 \pm 0.9$ & $0.3 \pm 0.3$ \\
Meta/poly. & $65.4 \pm 7.5$ & $48.0 \pm 8.3$ & $33.2 \pm 7.9^{\mathrm{a}}$ \\
Lymphocytes & $15.2 \pm 2.2$ & $25.9 \pm 6.3$ & $11.0 \pm 2.7$ \\
Monocytes & $9.8 \pm 1.4$ & $12.7 \pm 1.8$ & $10.8 \pm 3.1$ \\
Eosinophils & $0.2 \pm 0.2$ & $0.1 \pm 0.1$ & $0.3 \pm 0.3$ \\
Nucleated erythrocytes & $7.2 \pm 5.2$ & $11.4 \pm 5.8$ & $44.3 \pm 12.1^{\mathrm{b}}$ \\
\hline
\end{tabular}

(Meta/poly.) Metamyeloctye/polymorphonuclear leukocyte. Means \pm SEM; $n=8 \mathrm{Moz}^{\Delta / \Delta}, 8 \mathrm{Moz}^{\Delta /+}$, and $6 \mathrm{Moz}^{+/+}$E18.5 pups; $\mathrm{Moz}^{\Delta / \Delta} \neq \mathrm{Moz}^{+/+}:{ }^{\mathrm{a}} \mathrm{P}<0.05 ;{ }^{\mathrm{b}} \mathrm{P}<0.01$.

curs. The slight increase in nucleated erythrocytes may be caused by the absence of a spleen in the mutant mice.

The Moz gene is widely expressed during development and in adult animals

We examined the expression pattern of the Moz gene by Northern blot, in situ hybridization and quantitative RT-PCR. During embryonic development Moz is widely expressed throughout the embryo, being present in all organs. However the level of expression varied substantially. The strongest expression domain at E13.5 was in the mesencephalon, with lower levels of expression in the spinal cord and telencephalon. Outside of the central nervous system, higher levels of expression were found in the thymus, the dorsal root ganglia, and the nasal epithelium at E13.5. Lower levels of expression were found in the lung, although expression was prominent in the epithelial layer, and in the fetal liver (Fig. 3A-C). At later stages of development strong expression was seen in the surface ectoderm, the incisors, and the whisker follicles (data not shown). Moz mRNA was detected in all adult organs examined by Northern blot with higher levels of expression seen in the thymus and lung. The mRNA levels in the thymus and lung were similar to the average level in the E12.5 embryo, whereas other adult organs contained lower levels of expression (Fig. 3D). Moz mRNA was detected in all hematopoietic progenitor populations as well as in the $\mathrm{Sca}-1^{+} \mathrm{c}-\mathrm{Kit}^{+}$lineage cell population enriched for hematopoietic stem cells. By quantitative RT-PCR the Moz mRNA levels in hematopoietic progenitor cell populations were similar to, or greater than, the mRNA levels found in whole midgestation embryos (Fig. 3E).

The Moz ${ }^{\Delta}$ mutation causes a profound reduction in the number of hematopoietic progenitors; however, it does not affect lineage commitment

Since the hematopoietic system has a large capacity to compensate for defects in progenitor cell populations, we examined lineage-committed progenitors at E12.5 in the fetal liver and at E18.5 in both fetal liver and bone marrow using colony-forming cell assays. These assays showed that there was a profound reduction in the num- ber of committed progenitors (Table 2). Significantly for the development of the fetus, erythroid progenitors were less severely affected than other lineages, although only $\sim 30 \%$ of the normal number of erythroid colonies was present in the mutant fetal liver cells compared with wild-type cells. Bipotential granulocyte/macrophage progenitors and megakaryocyte/erythroid progenitors (Supplementary Fig. 2) were detected, suggesting that no significant difference in the hierarchy of blood formation occurs in the mutant animals as compared with wildtype animals. Although none of the rare eosinophilic colony-forming cells were found, the blood of $\mathrm{Moz}^{\Delta / \Delta}$ mutant fetuses contained eosinophils, indicating that progenitors for this lineage can be formed in homozygous animals. The $M o z^{\Delta / \Delta}$ mutant cells were capable of
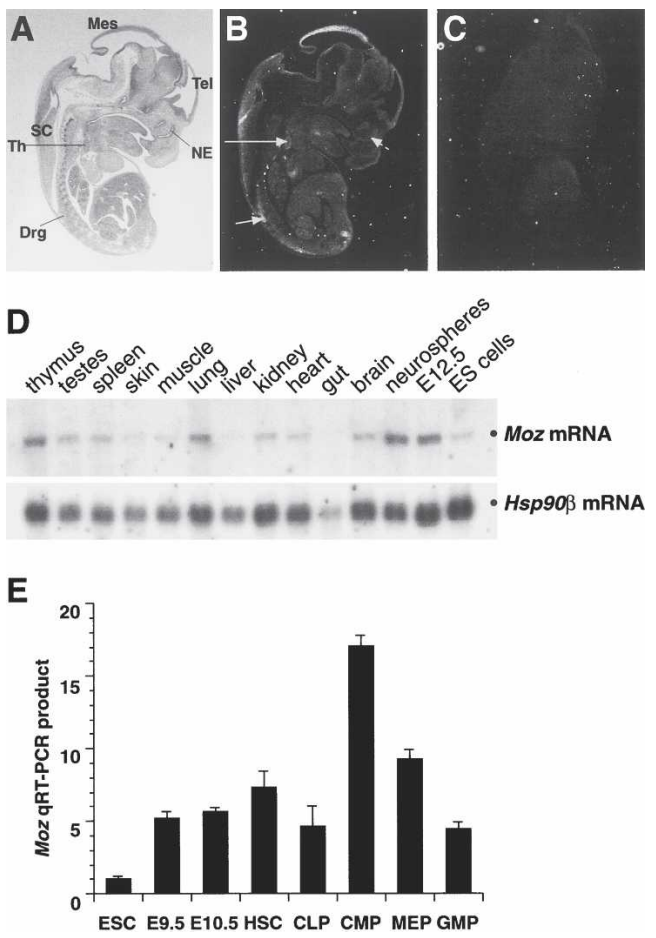

Figure 3. Moz is widely expressed both during embryogenesis and in the adult at low levels. $(A-C)$ Radioactive in situ hybridization using a $2.8-\mathrm{kb}$ probe to exon 16 . Bright-field $(A)$ and corresponding dark-field $(B)$ images show that $M o z$ is expressed in the thymus (Th, long arrow), the telencephalon (Tel), and nasal epithelium (NE, stippled arrow) at E13.5. In addition, $M o z$ is expressed prominently in the dorsal root ganglia (Drg, short arrow), mesencephalon (Mes), and spinal cord (SC). (C) Sense control shows no hybridization above background. $(D$, top $)$ Northern analysis, $10 \mu \mathrm{g}$ total RNA per lane, shows Moz is expressed in most adult tissues, particularly in the thymus and lung where levels are similar to whole E12.5 embryo. Multipotent, proliferating cells isolated from adult brain and cultured as neurospheres also express Moz. (Bottom) Hsp90 $\beta$ mRNA as loading and transfer control. (E) Quantitative RT-PCR showing detection of Moz mRNA in cDNA prepared from hematopoietic stem cells (HSC), common lymphoid progenitors (CLP), common myeloid progenitors (CMP), megakaryocyte/erythroid progenitors (MEP), and granulocyte/macrophage progenitors (GMP) as compared with ES cells and E9.5 and E10.5 embryos. 
Table 2. Moz mutant E12.5 and E18.5 liver and bone marrow colony-forming cells in cultures stimulated with SCF + IL-3 + EPO per 20,000 cells plated

\begin{tabular}{|c|c|c|c|}
\hline Colony type & $\mathrm{Moz}^{+/+}$ & $M o z^{\Delta /+}$ & $M o z^{\Delta / \Delta}$ \\
\hline \multicolumn{4}{|l|}{ Liver E12.5 } \\
\hline Blast cell & $4.0 \pm 2.7$ & $4.5 \pm 0.9$ & $0.8 \pm 0.5$ \\
\hline Granulocyte & $20.0 \pm 6.8$ & $7.2 \pm 1.9^{\mathrm{b}}$ & $1.3 \pm 0.5^{\mathrm{c}, \mathrm{e}}$ \\
\hline Granuloytes/macrophage & $8.5 \pm 3.9$ & $4.2 \pm 1.4^{\mathrm{b}}$ & $3.3 \pm 1.4^{\mathrm{b}}$ \\
\hline Macrophage & $31.3 \pm 14.3$ & $13.2 \pm 2.3^{\mathrm{a}}$ & $5.0 \pm 1.9^{\mathrm{c}, \mathrm{d}}$ \\
\hline Eosinophil & $0.8 \pm 0.5$ & $0.1 \pm 0.1^{\mathrm{b}}$ & $0 \pm 0^{\mathrm{b}}$ \\
\hline Erythroid & $93.5 \pm 32.3$ & $63.5 \pm 11.3$ & $28.5 \pm 4.5^{\mathrm{a}, \mathrm{d}}$ \\
\hline Megakaryocyte & $7.8 \pm 5.3$ & $9.8 \pm 2.6$ & $1.0 \pm 0.4^{\mathrm{a}, \mathrm{d}}$ \\
\hline Megakaryocyte/erythrocyte & $14.2 \pm 5.3$ & $9.8 \pm 2.6$ & $1.0 \pm 0.4^{\mathrm{a}, \mathrm{e}}$ \\
\hline \multicolumn{4}{|l|}{ Liver E18.5 } \\
\hline Blast cell & $17.0 \pm 2.6$ & $6.0 \pm 1.5^{\mathrm{c}}$ & $0 \pm 0^{\mathrm{c}, \mathrm{e}}$ \\
\hline Granulocyte & $15.7 \pm 3.1$ & $10.3 \pm 1.3^{\mathrm{b}}$ & $1.5 \pm 0.7^{\mathrm{c}, \mathrm{f}}$ \\
\hline Granulocyte/macrophage & $16.0 \pm 2.3$ & $7.3 \pm 2.7^{\mathrm{b}}$ & $2.8 \pm 1.5^{\mathrm{c}, \mathrm{d}}$ \\
\hline Macrophage & $26.0 \pm 3.5$ & $20.5 \pm 5.9^{\mathrm{a}}$ & $3.4 \pm 2.0^{\mathrm{c}, \mathrm{e}}$ \\
\hline Eosinophil & $0.3 \pm 0.3$ & $0 \pm 0^{\mathrm{b}}$ & $0 \pm 0^{\mathrm{b}}$ \\
\hline Erythroid & $8.3 \pm 2.0$ & $7.5 \pm 1.5$ & $2.8 \pm 1.2^{\mathrm{a}, \mathrm{d}}$ \\
\hline Megakaryocyte & $5.0 \pm 1.5$ & $3.8 \pm 1.9$ & $0 \pm 0^{\mathrm{b}, \mathrm{d}}$ \\
\hline Megakaryocyte/erythrocyte & $4.0 \pm 1.2$ & $5.0 \pm 0.6$ & $0 \pm 0^{\mathrm{a}, \mathrm{e}}$ \\
\hline Megakaryocyte/blast cell & $1.7 \pm 0.9$ & $0 \pm 0^{\mathrm{b}}$ & $0 \pm 0^{\mathrm{b}}$ \\
\hline \multicolumn{4}{|l|}{ Bone marrow E18.5 } \\
\hline Blast cell & $5.0 \pm 2.0$ & $6.0 \pm 1.7$ & $0 \pm 0^{\circ}$ \\
\hline Granulocyte & $11.3 \pm 3.0$ & $12.0 \pm 4.7$ & $1.0 \pm 1.0^{\mathrm{c}, \mathrm{f}}$ \\
\hline Granulocyte/macrophage & $11.7 \pm 2.2$ & $7.1 \pm 2.2^{\mathrm{b}}$ & $0.7 \pm 0.7^{\mathrm{c}, \mathrm{d}}$ \\
\hline Macrophage & $12.3 \pm 1.8$ & $8.7 \pm 5.2$ & $0.3 \pm 0.3^{\mathrm{c}, \mathrm{e}}$ \\
\hline Eosinophil & $0.3 \pm 0.3$ & $0.7 \pm 0.7$ & $0 \pm 0$ \\
\hline Erythroid & $12.0 \pm 8.0$ & $8.0 \pm 4.6$ & $0.7 \pm 0.7^{\mathrm{a}}$ \\
\hline Megakaryocyte & $3.3 \pm 1.5$ & $0.7 \pm 0.7$ & $0 \pm 0^{\mathrm{b}}$ \\
\hline Megakaryocyte/erythrocyte & $1.3 \pm 0.7$ & $0.7 \pm 0.7$ & $0 \pm 0$ \\
\hline Megakaryocyte/blast cell & $0.7 \pm 0.7$ & $0 \pm 0^{\mathrm{b}}$ & $0 \pm 0^{\mathrm{b}}$ \\
\hline
\end{tabular}

Means \pm SEM; $n=3-5 \mathrm{Moz}^{\Delta / \Delta}, 3-13 \mathrm{Moz}^{\Delta /+}$, and 3-4 Moz ${ }^{+/+}$; homozygotes and heterozygotes differ from wild types at significance levels indicated. Data were analyzed by two-factorial analysis of variance with genotype and developmental stage (E12.5 and E18.5 liver) or genotype and organ (E18.5 liver and bone marrow) as the two independent factors.

${ }^{\mathrm{a}} P<0.05$.

${ }^{\mathrm{b}} P<0.01$

${ }^{\mathrm{c}} P<0.001$, homozygotes differ from heterozygotes at significance levels indicated.

${ }^{\mathrm{d}} P<0.05$.

${ }^{\mathrm{e}} P<0.01$.

${ }^{\mathrm{f}} P<0.001$.

differentiating into all cell lineages. However, we observed that the average size of the mutant colonies was reduced, particularly those formed from E18.5 fetal liver cells.

Overall fetal liver hematopoietic cellularity was reduced in the mutants at E12.5, E15.5, and E18.5 (77 $\pm 3 \%$ of wild type, $P<0.0001)$. The number of myeloid colonyforming cells was also significantly reduced in fetal liver of heterozygous animals at both E12.5 and E 18.5 (Table 2 ). The mutant bone marrow at E18.5 was severely affected, having both low cellularity $(32 \pm 9 \%$ of wild type, $P<0.0001)$ and very low numbers of progenitors. Therefore, colonization of the bone marrow by progenitors takes place in the $\mathrm{Moz}^{\Delta / \Delta}$ animals, but hematopoiesis is not efficiently established. In addition, the relative number of colony-forming progenitor cells in the $M o z^{\Delta / \Delta}$ fetus declined from $36.1 \pm 9.8 \%$ of the wild-type littermate value at E12.5 to $6.8 \pm 2.5 \%$ of the wild-type value at E18.5 $(P<0.01)$, showing that there was a failure to maintain early progenitors numbers in the $\mathrm{Moz}^{\Delta / \Delta} \mathrm{mu}$ tant fetuses.

Early hematopoietic progenitors and stem cells in the fetal liver express a characteristic set of cell surface markers, including c-Kit (Morrison et al. 1995), Sca-1 (Morrison et al. 1995), AA4.1 (Jordan et al. 1995) and Flt-3 (Zeigler et al. 1994). The majority of lineage-specific cell surface markers are not detectable on these cells ( $\left.\operatorname{Lin}^{\text {neg }}\right)$. We used fluorescence-activated cell analysis to determine the size of the $\mathrm{c}-\mathrm{Kit}^{+} \mathrm{Sca}-1^{+} \mathrm{Lin}{ }^{\text {neg }}$, c-Kit ${ }^{+} \mathrm{Flt}-3^{+} \mathrm{Lin}^{\text {neg }}$, and $\mathrm{c}-\mathrm{Kit}^{+} \mathrm{AA} 4.1^{+} \mathrm{Lin}^{\text {neg }}$ populations at E14.5. The fraction of $\mathrm{c}-\mathrm{Kit}^{+} \mathrm{Lin}^{\text {neg }}$ cells, representing predominantly committed progenitors with limited proliferative capacity, was normal in the mutant animals. However each of the early progenitor/stem cell 
A
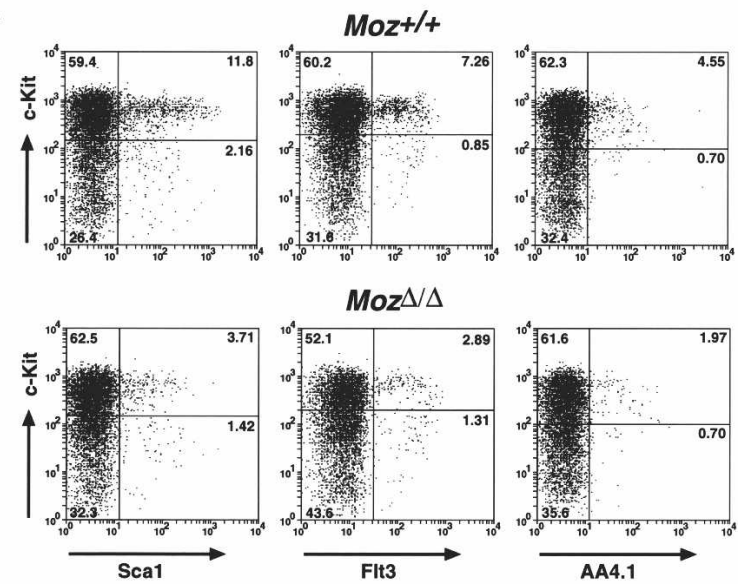

B 10

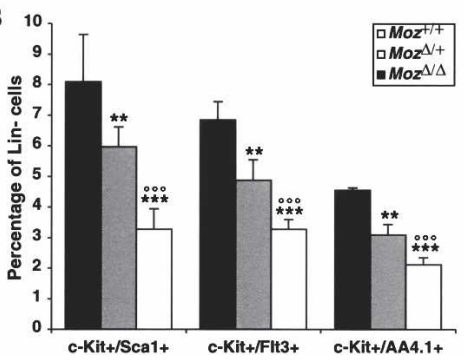

Figure 4. Fluorescence-activated cell analysis of early progenitor/stem cell populations in $\mathrm{Moz}^{\Delta / \Delta}, \mathrm{Moz}^{\Delta /+}$, and $\mathrm{Moz}^{+/+}$littermate fetal livers at E14.5. Fetal liver cells were stained with a cocktail of FITC-conjugated antibodies against the lineage markers Ter119, Gr-1 CD4, CD8, B220, and CD19. Mac-1 was not included, since fetal liver stem cells have been reported to be mac-1-positive (Morrison et al. 1995). In addition, cells were labeled with APC-conjugated c-Kit antibody and with either PE-conjugated anti-Scal or anti-AA4.1 or biotinylated antiFlk2/Flt3 followed by PE-conjugated streptavidin. (A) Fluorescence-activated cell analysis profiles are shown for $\mathrm{Moz}^{+/+}$fetal livers and $\mathrm{Moz}^{\Delta / \Delta}$ littermate fetal livers. The lineage-negative cell population was analyzed for c-Kit-, Sca1-, Flt3-, or AA4.1positive cells as indicated. (B) Quantification of fluorescenceactivated cell analysis results: $n=6 \mathrm{Moz}^{\Delta / \Delta}, 3 \mathrm{Moz}^{\Delta /+}$, and 3 $\mathrm{Moz}^{+/+}$littermate fetal livers; $\left.\mathrm{Moz}^{\Delta / \Delta} ; \mathrm{Moz}^{\Delta /+} \neq \mathrm{Moz}^{+/+} ;{ }^{\star \star \star \star}\right)$ $\left.P<0.001 ;\left.\right|^{\star \star}\right) P<0.01 ; M o z^{\Delta / \Delta} \neq M o z^{\Delta /+} ;\left(^{\circ 00}\right) P<0.001$. Note the reduction in early progenitor/stem cell numbers in the $M o z^{\Delta / \Delta}$ mutant and the intermediate levels in the $\mathrm{Moz}^{\Delta /+}$ heterozygotes. Data were analyzed by two-factorial analysis of variance with genotype and cell surface marker set as the independent factors, followed by Fisher's post-hoc test.

populations, c-Kit ${ }^{+} \mathrm{Sca}-1^{+} \mathrm{Lin}^{\text {neg }}, \mathrm{c}-\mathrm{Kit}^{+} \mathrm{Flt}-3^{+} \mathrm{Lin}^{\text {neg }}$, and c-Kit ${ }^{+} \mathrm{AA} 4.1^{+} \mathrm{Lin}^{\text {neg }}$ was reduced by $>50 \%$ in mutant animals compared with controls (Fig. 4). Interestingly, all three of these early progenitor/stem cell populations showed an intermediate reduction in the heterozygous animals (Fig. 4).

\section{The Moz ${ }^{\Delta}$ mutation diminishes T-cell production} in the thymus, but $T$ cells mature normally

The thymus is a site of Moz gene expression (Fig. 3), and since the Moz mutant thymus was highly dysgenic, we assessed lymphoid development in the thymus of $M o z^{\Delta / \Delta}$ animals. We observed a substantial reduction in the number of lymphoid cells in the mutant thymus $(6.7 \pm 2 \%$ of wild type, $P<0.0001)$ (Fig. $5 \mathrm{~A})$, similar to the reduction in myeloid and erythroid colony-forming cells in the fetal liver. Likewise, there was a significant reduction in the number of lymphoid cells in heterozygous animals. However, $\mathrm{Moz}^{\Delta / \Delta}$ mutant lymphoid progenitors were able to differentiate into CD8 and CD4 double-positive cells (Fig. 5B). The fraction of doublepositive cells in the mutant and wild type was similar,
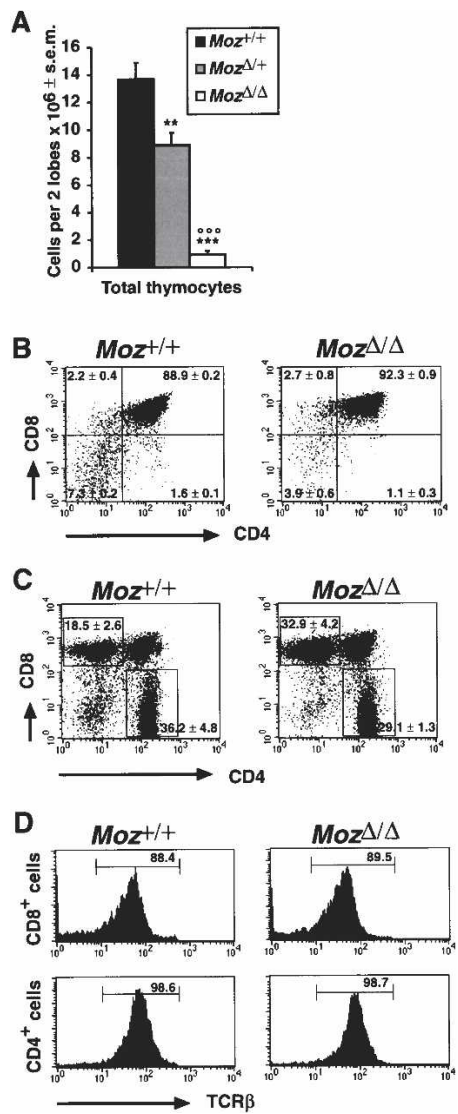

Figure 5. The thymus of $M o z^{\Delta / \Delta}$ homozygous animals is able to support the differentiation of $\mathrm{T}$ cells. $(A)$ Total cellularity of the $M o z^{\Delta / \Delta}$ homozygous thymus is low at E18.5, with heterozygous animals having an intermediate cellularity: $n=5 \mathrm{Moz}^{\Delta / \Delta}$,

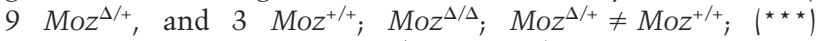
$\left.P<0.0001 ;{ }^{\star \star}\right) P<0.01 ; M^{*} z^{\Delta / \Delta} \neq M o z^{\Delta /+} ;\left({ }^{000}\right) P<0.0001$. (B) Fluorescence-activated cell analysis shows the proportion of CD4/CD8 double-positive thymocytes is normal in $M o z^{\Delta / \Delta}$ homozygous compared with littermate controls $\left(\mathrm{Moz}^{+/+}\right)$at E18.5. There is a significant reduction in the number of double-negative cells in the $M o z^{\Delta / \Delta}$ homozygotes $(P<0.05)$. $(C, D)$ After $12 \mathrm{~d}$ of fetal thymic organ culture, thymocytes of both $\mathrm{Moz}^{\Delta / \Delta}$ homozygous and littermate controls $\left(\mathrm{Moz}^{+/+}\right)$underwent further maturation to form both CD4 and CD8 single-positive cells $(C)$ and recombined the T-cell receptor $\alpha \beta$ subunits (TCR $\beta$ in $D)$. Levels of TCR $\beta$ expression of single-positive cells gated in $C$ are shown in $D$. Data were analyzed by one-factorial analysis of variance with genotype as the independent factor, followed by Fisher's post-hoc test. 
$\sim 90 \%$. However in the mutant animals there was a significant reduction in fraction of double-negative cells (Fig. 5B).

CD8/CD4 double-positive cells are intermediates in T-cell maturation (Anderson et al. 1999). Further maturation of $\mathrm{T}$ cells occurs after birth. To study subsequent steps in differentiation, fetal thymi were maintained in organ culture for $12 \mathrm{~d}$. We found that $\mathrm{Moz}^{\Delta / \Delta} \mathrm{T}$-cell progenitors matured to form CD8 and CD4 single-positive cells (Fig. 5C) and underwent T-cell receptor recombination to become $\alpha \beta$ TCR-positive (Fig. 5D). In addition, $\gamma \delta$ TCR receptor cells were formed by $\mathrm{Moz}^{\Delta / \Delta} \mathrm{T}$-cell progenitors (data not shown). These results show that although the total number of lymphoid progenitors and total T-cell production was severely reduced in the $M o z^{\Delta / \Delta}$ thymus, these cells were able to undergo normal T-cell maturation and the $M o z^{\Delta / \Delta}$ thymic epithelium was able to support T-cell development.

\section{Moz is required in hematopoietic stem cells}

Together, the results presented above showed that the $M o z^{\Delta}$ mutation causes a severe reduction in the number of committed progenitors of myeloid, erythroid, and lymphoid lineages, but is compatible with differentiation of progenitors once they are formed. This implies that Moz is required in precursors of the lineage-committed progenitors, the hematopoietic stem cells (Fig. 6A). A characteristic feature of hematopoietic stem cells is their ability to reconstitute the hematopoietic system of a lethally irradiated mouse. To determine if Moz was required in stem cells we tested the ability of fetal liver cells from homozygous $M o z^{\Delta / \Delta}$ mutant embryos at E15.5 to reconstitute the hematopoietic system of recipient mice. The irradiation conditions used were sufficient to ablate the recipients' hematopoietic system, making survival dependent on the ability of the donor cells to reestablish hematopoiesis (Kondo et al. 2003). A total of 17 recipients were injected with fetal liver cells from five different $\mathrm{Moz}^{\Delta / \Delta}$ embryos (three to five recipients per donor; $10 \times 10^{6}$ to $19 \times 10^{6}$ fetal cells per recipient). No recipients receiving donor cells from $\mathrm{Moz}^{\Delta / \Delta}$ embryos survived beyond $28 \mathrm{~d}$ (Fig. 6B). All recipients receiving fetal liver cells from either heterozygous or wild-type littermates survived, and remained healthy for at least 3 mo. The first few weeks of recovery from radiation require short-term repopulating cells to generate sufficient erythrocytes to avoid aplastic anemia. The rapid death of recipients receiving mutant cells suggests that $M o z^{\Delta / \Delta}$ embryos have a severe lack of functional short-term repopulating hematopoietic cells.

The number of colonies formed on the spleens of irradiated recipients $12 \mathrm{~d}$ after reconstitution $\left(\mathrm{CFU}-\mathrm{S}_{12}\right)$ is an assay of primitive, multipotent, hematopoietic cells (Till and McCulloch 1961; Jones et al. 1990) and primarily enumerates short-term repopulating cells (van der Loo et al. 1994). We performed CFU-S ${ }_{12}$ assays using fetal liver cells isolated at E12.5, E15.5, and E18.5. At each stage, $\mathrm{Moz}^{\Delta / \Delta}$-derived colonies of normal size were detected on spleens examined at day 12 after injection (Fig. 6C).
However, consistent with the reconstitution assay, these colonies were present in lower numbers than those produced from the fetal liver of wild-type littermate controls $(9.0 \pm 1.5 \%$ of wild type; $P<0.0001)$ (Fig. 6D). In addition, at all stages examined, there was a reduction in the number CFU-S ${ }_{12}$ in heterozygous animals (Fig. 6D).

To determine if $\mathrm{Moz}^{\Delta / \Delta}$ mutant embryos contain detectable numbers of long-term repopulating hematopoietic stem cells, we performed competitive reconstitution assays (Harrison et al. 1993). In these experiments, fetal liver cells isolated from E15.5 embryos derived from $M o z^{\Delta /+}$ heterozygous intercrosses were combined with wild-type fetal liver cells. The presence of wild-type cells in these experiments supplied sufficient short-term repopulating cells to prevent the recipients from developing severe anemia. Specific isoforms of the cell surface protein CD45 (Ly5) (Scheid and Triglia 1979) were used to distinguish wild-type "competitor" cells (CD45.1positive) from "test" cells derived from $\mathrm{Moz}^{\Delta /+}$ heterozygous intercrosses (CD45.1/45.2 double-positive) (Fig. 6 E). Peripheral blood from recipients was examined at 6 , 12-14, and 22 wk after reconstitution. While $\mathrm{Moz}^{+/+}$fetal liver cells reconstituted the hosts' hematopoietic system to a larger extent than wild-type competitor cells, no contribution of littermate homozygous $\mathrm{Moz}^{\Delta / \Delta}$ cells could be detected above background in the peripheral blood at any stage (Fig. 6F,G). In addition, DNA was prepared from bone marrow of recipient mice at $22 \mathrm{wk}$ and the presence of the mutant Moz allele was determined by Southern gel blot and by PCR. The mutant Moz allele was not detected in DNA purified from the bone marrow of recipients when the donor (test) cells were derived from a $M o z^{\Delta / \Delta}$ fetal liver. Since the bone marrow contains large numbers of nucleated red blood cell progenitors, this indicates that the $M o z^{\Delta / \Delta}$ fetal liver cells are unable to contribute to the erythroid lineage irrespective of the presence of wild-type fetal liver cells. A highly statistically significant reduction in the ability of fetal liver cells from heterozygous animals to compete with wild-type fetal liver cells was also observed. As in the CFU-S $_{12}$ assays (Fig. 6D) the heterozygous animals displayed an intermediate phenotype in competitive reconstitution assays (Fig. 6F).

In these experiments cells from individual $\mathrm{Moz}^{\Delta / \Delta}$ homozygous fetal livers were mixed with wild-type competitor cells in 1:1 and 4:1 ratios and injected into a total of six recipient mice. For each homozygous embryo $(n=4)$ a total of $15 \times 10^{6}$ fetal cells were transferred. Long-term repopulation units are more abundant in wild-type fetal liver cells than in bone marrow. A conservative estimate of one repopulating unit per $10^{5}$ adult bone marrow cells (Harrison et al. 1993), and a minimum estimate of fourfold greater abundance of stem cells in fetal liver (Jordan et al. 1995; Harrison et al. 1997) implies that there are at least four repopulating units per $10^{5}$ cells in a wild-type fetal liver. As we detected no long-term reconstituting cells in a total of $6 \times 10^{7}$ cells from the $M o z^{\Delta / \Delta}$ fetal livers, the abundance of fully functional stem cells in the $M o z^{\Delta / \Delta}$ mutants is reduced by $>2000$-fold when compared with the wild-type fetal liver. 
In contrast, wild-type fetal liver "test" cells from littermate controls contributed more extensively to the hematopoietic system of recipient mice than the "competitor" cells (Fig. 6F,G).

\section{Discussion}

Hematopoiesis is organized in a hierarchy of differentiation steps, both in the fetal liver and in adult bone marrow, in which the progeny of stem cells become increasingly restricted to different lineages and in proliferative capacity (Dzierzak and Medvinsky 1995; Kondo et al. 2003). In the blood of $M o z^{\Delta / \Delta}$ mice all mature cell types were present and, particularly important for fetal development, the hematocrit was normal. However, increasingly severe phenotypic effects were seen as we examined more immature cell types. A profound reduction in
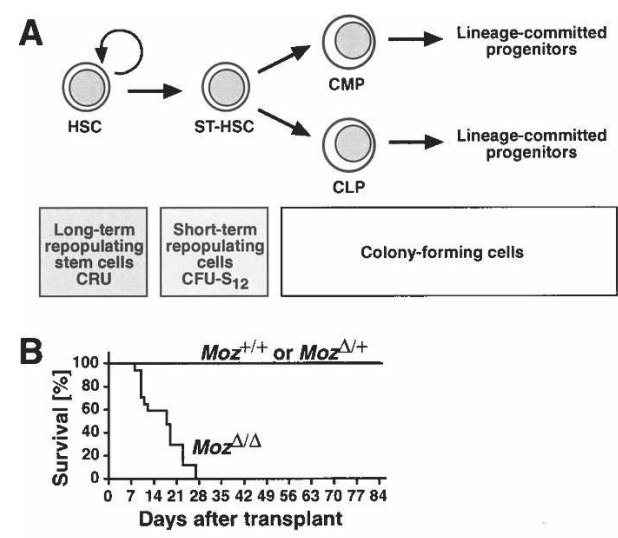

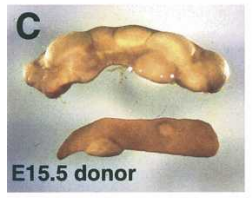

$\mathrm{E}$

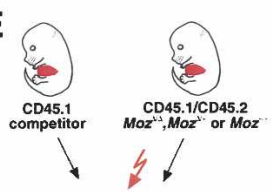

$\underset{\text { recipient }}{\text { CD45.2 }}$

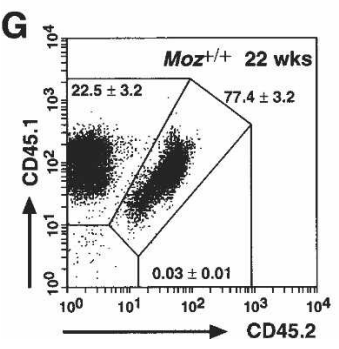

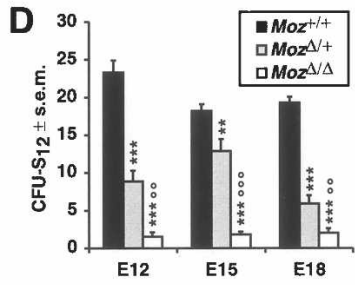
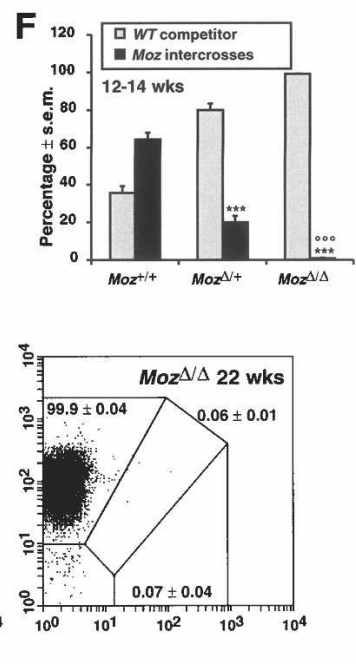

the number of committed progenitors was seen. The number of colony-forming cells declined during fetal development of the $\mathrm{Moz}^{\Delta / \Delta}$ mice relative to wild-type controls and hematopoiesis was not effectively established in the bone marrow. Nevertheless, progenitors of all lineages were present. We examined the development of $\mathrm{T}$ cells in detail. There was a large decrease in the number of committed progenitors (thymocytes) and a corresponding decrease in total T-cell output, but in common with myeloid and erythroid progenitors, the few thymo-

Figure 6. Fetal liver hematopoietic cells from $\mathrm{Moz}^{\Delta / \Delta}$ homozygous animals are severely deficient in short-term and longterm repopulating stem cells. (A) Schematic diagram showing the relationship between long-term repopulating cells (HSC) detected by competitive repopulation unit (CRU) assays, shortterm repopulating cells (ST-HSC) detected by spleen colonyforming unit assays $\left(\mathrm{CFU}-\mathrm{S}_{12}\right)$, and lineage-committed progenitors identified in colony-forming cell assays. (B) Survival curve showing that lethally irradiated recipients receiving either heterozygous or wild-type E15.5 fetal liver cells from $\mathrm{Moz}^{\mathrm{\Delta /+}}$ intercrosses survive, whereas mice receiving homozygous littermate cells die within $28 \mathrm{~d}\left(n=17,16\right.$, and 8 mice receiving $M o z^{\Delta / \Delta}$, $\mathrm{Moz}^{\Delta /+}, \mathrm{Moz}^{+/+}$cells, respectively). Mice were intravenously injected with $10 \times 10^{6}$ to $19 \times 10^{6}$ cells. There was no correlation between the survival times of mice receiving a small or large number of homozygous cells. $(C)$ CFU-S $_{12}$ assays. Lethally irradiated recipients were injected with fetal liver cells from $\mathrm{Moz}^{\Delta /+}$ intercrosses at E12.5, E15.5, or E18.5. (Top) A representative spleen of mice injected with E15.5 wild-type $\left(\mathrm{Moz}^{+/+}\right)$fetal cells. (Bottom) A representative spleen of mice receiving cells from littermate $M o z^{\Delta / \Delta}$ fetuses. (D) Absolute counts of spleen colonies larger than $0.5 \mathrm{~mm}: n=11 \mathrm{Moz}^{\Delta / \Delta}$ donors, $15 \mathrm{Moz}^{\Delta /+}$ donors, and $15 \mathrm{Moz}^{+/+}$donors; $\mathrm{Moz}^{\Delta / \Delta} ; \mathrm{Moz}^{\Delta /+} \neq \mathrm{Moz}^{+/+} ;\left(^{\star \star \star}\right)$ $\left.P<0.001 ;{ }^{* \star}\right) P<0.01 ; \mathrm{Moz}^{\Delta / \Delta} \neq \mathrm{Moz}^{\Delta /+} ;\left({ }^{000}\right) P<0.0001 ;\left({ }^{\circ}\right)$ $P<0.01$. Note the paucity of CFU-S 12 cells derived from Moz ${ }^{\Delta / \Delta}$ animals and the intermediate levels derived from $\mathrm{Moz}^{\Delta /+}$ heterozygotes $(D)$. Data were analyzed by two-factorial analysis of variance with genotype and developmental stage as the independent factors, followed by Fisher's post-hoc test. $(E)$ CRU assays. Lethally irradiated mice received a mixture of wild-type cells $\left(1 \times 10^{6}\right)$ and cells from $\mathrm{Moz}^{\Delta /+}$ intercrosses at E15.5. Wildtype "competitor" cells were identified by the presence of the CD45.1 isoform, the "test" cells from $\mathrm{Moz}^{\Delta /+}$ intercrosses expressed both CD45.1 and CD45.2 isoforms, and any residual cells from the irradiated recipient expressed CD45.2 only. In different experiments, competitor cells and test cells were mixed in ratios of $1: 1$ and $1: 4 .(F, G)$ Combined fluorescenceactivated cell analysis of peripheral blood leukocytes results from all experiments performed at $12-14 \mathrm{wk}(F)$, and at $22 \mathrm{wk}$ $(G)$ after reconstitution show extensive contribution of wildtype $\left(\mathrm{Moz}^{+/+}\right)$fetal cells but no detectable contribution from homozygous littermates $\left(\mathrm{Moz}^{\Delta / \Delta}\right)$. (F) $\mathrm{Moz}^{\Delta /+}$ heterozygotes show an intermediate ability to competitively reconstitute the hosts. $(G)$ Contribution of each CD45-isoform-positive population is indicated for experiments using wild-type $\left(\mathrm{Moz}^{+/+}\right)$and homozygous $\left(M o z^{\Delta / \Delta}\right)$ fetal liver cells. Data are presented as combined percentage contribution after normalizing all input levels to a 1:1 ratio: $n=4 \mathrm{Moz}^{\Delta / \Delta}$ donors, $9 \mathrm{Moz}^{\Delta /+}$ donors, and $7 \mathrm{Moz}^{+/+}$donors; $\mathrm{Moz}^{\Delta / \Delta} ; \mathrm{Moz}^{\Delta /+} \neq \mathrm{Moz}^{+/+} ;\left(^{\star \star \star}\right) \mathrm{P}<0.0001$; $\left.M o z^{\Delta / \Delta} \neq M o z^{\Delta /+} ;{ }^{(000}\right) P<0.0001$. Data were analyzed by onefactorial analysis of variance with genotype as the independent factor, followed by Fisher' post-hoc test. 
cytes present were able to differentiate normally. These results show that the $M o z^{\Delta / \Delta}$ mutation does not affect lineage commitment and differentiation of progenitors once they are formed, but that there is a lack of committed progenitors.

Interestingly, we observed a strong heterozygous phenotype in the number of colony-forming cells, the number of early progenitors and in reconstitution assays. This shows that there is a strong gene dosage requirement for Moz. Sensitivity to gene dosage has also been found in the coactivators CBP and p300 (Yao et al. 1998; Kung et al. 2000). These coactivators also contain a histone acetyltransferase domain (Yang 2004). The observation that the Moz mutation also shows strong gene dosage effects supports the notion proposed for CBP: that coactivators with histone acetyltransferase activity may be limiting in many cellular processes (Kamei et al. 1996).

Definitive hematopoiesis takes place in $\mathrm{Moz}^{\Delta / \Delta}$ mice, at reduced cellularity, and the full range of mature blood cell types can be produced. Aml1 is required for the development of definitive hematopoiesis (Okuda et al. 1996; Wang et al. 1996) and T-cell differentiation (Ichikawa et al. 2004). We have demonstrated that Moz, while able to stimulate activation of AML1 in vitro through it's C-terminal domains (Kitabayashi et al. 2001a), is not essential for the Amll function in initiation of definitive hematopoiesis in vivo or for the lineage-specific function of Amll in T-cell development.

Our results show that mutating the Moz gene results in the absence of long-term repopulating stem cells and a substantial reduction in the number of multipotent cells able to form spleen colonies. In addition to these indirect assays, we have shown directly by flow cytometry that early progenitor/stem cell populations are greatly reduced in the $M o z^{\Delta / \Delta}$ mice. These results show that Moz functions specifically in the hematopoietic stem cell compartment. In this context it is interesting that the MOZ-TIF2 fusion protein is able to induce leukemic stem cell self-renewal (Huntly et al. 2004). This activity requires the nucleosome-binding domain of MOZ and suggests that MOZ has the capacity to interact with the chromatin of genes controlling self-renewal (Deguchi et al. 2003; Huntly et al. 2004).

How do the $M o z^{\Delta / \Delta}$ mice maintain relatively normal peripheral blood cellularity until birth with severe defects in the hematopoietic stem cell compartment? Our results are consistent with a requirement for $\mathrm{Moz}$ in maintaining stem cell numbers. We have shown that in Moz mutant mice hematopoietic cells differentiate, form multipotent progenitors with limited capacity for selfrenewal, do not have a significant homing defect (as shown by the presence of cells able to form spleen colonies of normal size), and colonize the bone marrow of mutant fetuses. Multipotent cells are therefore present in sufficient numbers to produce lineage-committed progenitors early in gestation, and avoid phenotypic consequences of the loss of Moz function in the peripheral blood before birth, but cannot sustain long-term repopulation of an irradiated host after transplantation. A gradual loss of hematopoietic capacity is, however, already apparent in the Moz mutant animals before birth, since the total number of colony-forming cells declines from E12.5 to E18.5.

In conclusion, we have shown that Moz, which is a target of translocations leading to leukemia, has an essential function in hematopoiesis. We have previously shown that the closely related protein Querkopf has an essential function in neural stem cells, both during fetal development (Thomas et al. 2000) and in the adult (Rietze et al. 2001). Together, these results show that these histone acetyltransferases specifically regulate diverse stem cell populations.

\section{Materials and methods}

\section{Antibodies}

Anti-Flt3 (A2F10.1), anti-CD19 (ID3), anti-B220 (RA3-6B2), anti-Gr.1 (RA6-8C5), anti-Ter119, anti-CD4 (GK1.5), antiCD8 (YTS169.4), and anti-TCR (H57-597) were purified from hybridoma supernatants and biotinylated in the authors' laboratories. Anti-Sca1-PE, anti-c-Kit-APC, anti-AA4.1-PE, CD45.1FITC, CD45.2-PE, and streptavidin-PE were purchased from BD Pharmingen. Anti-CD4 -FITC and anti-CD8 -PE were purchased from Caltag. Anti-Neomycin Phosphotransferase (polyclonal IgG raised against the full-length protein) was purchased from Upstate Biotechnology (\#06-747).

\section{Generation of the mutant allele}

The homologous recombination construct was generated using a C57B/6 BAC, RP23-463A1, which contains all coding exons of the Moz gene. The $5^{\prime}$ arm consists of $3.8 \mathrm{~kb}$ of $\mathrm{Moz}$ genomic sequences ending at a point equivalent to the break point in Moz in the $t(8 ; 16)$ translocation (Borrow et al. 1996) found in human leukemia. The $5^{\prime}$ arm was partially generated by PCR and checked by sequencing. The $3^{\prime}$ arm consisted of the $8.3-\mathrm{kb}$ Nco1-BamH1 fragment $3^{\prime}$ of the break point. These fragments were cloned into a vector $5^{\prime}$ and $3^{\prime}$, respectively, of a promoterless neomycin phosphotransferase (neo) gene equipped with a $P g k-1$ polyadenylation sequence to produce the final construct pMoz17. The neo coding sequence was cloned in-frame with the remaining Moz coding sequences. This construct was linearized and electroporated into MPI-II cells (Voss et al. 1997). Transgenic embryonic stem (ES) cell clones were selected on the basis of G418 resistance. However, ES cell clones containing one homologously recombined Moz allele grew poorly, consistent with the Moz-neo fusion protein being present at low levels within the cells. Correctly targeted ES cell clones (11 from 104 G418resistant clones) were identified by Southern gel blots, as shown in Figure 1, and chimeras were generated by morula aggregation (Voss et al. 1997). After homologous recombination, the last six amino acids encoded by the mutated Moz gene are His, Ser, Gln, Gln, Val, and Val. Germline chimeras were produced from two independent ES cell clones, Moz17-51 and Moz17-69. Due to very low fertility of heterozygous mice on inbred $\mathrm{C} 57 \mathrm{~B} / 6$ or $129 \mathrm{~Sv}$ backgrounds, experiments were done using mice backcrossed to FVB/BalbC F1 hybrids. Since FVB mice carry the CD45.1 allele and BalbC mice carry the CD45.2 allele, this allows us to generate $M o z^{\Delta}$ intercrosses in which all progeny have the genotype CD45.1/CD45.2. The phenotype of homozygous mice derived from both Moz17-51 and Moz17-69 lines were identical; however, results are presented for line Moz17-51. 
Gross pathology and histology were performed as described previously (Thomas et al. 2000).

\section{Colony-forming cell assays}

Fetal liver colony-cell-forming assays were performed at E12.5 and E18.5. Suspensions of liver cells were cultured in $0.3 \%$ agar and stimulated to differentiate by the addition of purified murine growth factors, interleukin $3\left(10^{-3} \mathrm{U} / \mathrm{mL}\right)$, stem cell factor $(100 \mathrm{ng} / \mathrm{mL})$, and erythropoietin $(2 \mathrm{U} / \mathrm{mL})$. Cultures were incubated for $7 \mathrm{~d}$, then fixed, stained, and counted as described previously (Metcalf 1984).

\section{Transplantation assays}

CFU-S $_{12}$ assays were performed as described previously (Till and McCulloch 1961). Briefly, a fetal liver cell suspension was prepared by triturating fetal livers in $1 \mathrm{~mL}$ of phosphate-buffered saline containing $3 \%$ heat-inactivated fetal calf serum. Cells were counted and viability assessed by trypan blue exclusion. Recipients were lethally irradiated with two doses of 5.5 Gy (550 rads) generated from a $\left[{ }^{60} \mathrm{Co}\right] \gamma$-irradiation source, separated by $3 \mathrm{~h}$. Two hours later, recipient mice were injected via the tail vein with a fetal liver cell suspension containing $10^{6}$ cells. Three to five recipient mice were used per cell preparation. After $12 \mathrm{~d}$, the spleens were dissected from recipient mice and fixed in Bouin's fixative. Colonies were counted under a dissection microscope. Spleens were sectioned and sections were stained with hematoxylin and eosin. For long-term reconstitution experiments, recipient mice were lethally irradiated as described above for the CFU-S ${ }_{12}$ assays and then injected with cell suspensions prepared from fetal livers. The recipient mice lacked a functional Rag-1 gene (Spanopoulou et al. 1994) and were backcrossed onto a C57B/6 background for $>10$ generations. The absence of $\mathrm{T}$ cells in these mice prevented host versus graft reaction. The donor cells could be distinguished from any residual cells derived from the recipient mice because these would have expressed only the CD45.2 isoform. Competitive reconstitution assays were performed as described previously (Harrison et al. 1993). Fetal liver cell suspensions were prepared as above. Competitor cells $\left(10^{6}\right)$ from fetal livers dissected from mice carrying the CD45.1 allele were mixed with either $10^{6}$ or $4 \times 10^{6}$ test cells from fetuses derived from $\mathrm{Moz}^{\Delta /+}$ intercrosses (CD45.1/CD45.2 double-positive). After $6 \mathrm{wk}, 12-14 \mathrm{wk}$, and up to $22 \mathrm{wk}$, the peripheral blood leukocytes of recipient mice were analyzed for the expression of the cell surface marker CD45 as shown (Fig. 3).

\section{Fetal thymic organ cultures}

The thymi from E18.5 fetuses were dissected and maintained in culture on a floating support as described previously (Purton et al. 2000). Thymi were maintained in culture for $12 \mathrm{~d}$ with a single medium change on day 6 . On day 12 , thymocytes were isolated from thymic lobes and the proportion of CD4 and CD8 single-positive cells in addition to TCR-positive cells was determined by flow cytometry.

\section{Analysis of Moz gene expression}

Northern blot analysis was performed using a 482-base-pair (bp) probe coding for part of the MYST domain (exons 10-12 and part of exon 9). RNA samples and procedure were identical to those described in Voss et al. (2003). Hematopoietic progenitor populations were isolated by FACS based on their cell surface marker profile as described previously (Nutt et al. 2005). These were used to generate cDNA samples, and were then analyzed by quantitative PCR on an ABI prism 7900 (Applied Biosystems) using SYBR green (Qiagen QuantiTect) and protocols supplied by the manufacturer. Moz mRNA expression was normalized to HPRT mRNA.

Radioactive in situ hybridization, performed as described previously (Thomas et al. 2000) using a 2.8 -kb probe to Moz exon 16. Briefly, the probe was labeled by incorporating $\left[{ }^{35} \mathrm{~S}\right] \mathrm{CTP}$ (Amersham Biosciences) in an in vitro transcription reaction using either T3 or T7 RNA polymerase, hydrolyzed and incubated with deparaffinized tissue sections overnight at $55^{\circ} \mathrm{C}$ in a solution containing $50 \%$ formamide to increase stringency. Slides were washed at high stringency in SSC/50\% formamide at $60^{\circ} \mathrm{C}$ followed by RNase A treatment to remove singlestranded RNA molecules. Slides were then dipped in liquid emulsion (LM-1, Amersham Biosciences) and stored for 2-3 wk at $4^{\circ} \mathrm{C}$. Slides were then developed and lightly counter-stained with hematoxylin without differentiation.

Western blot analysis was performed using standard techniques. Briefly, embryos and adult organs were frozen on dry ice and stored at $-70^{\circ} \mathrm{C}$. Embryos and adult organs were lysed in ice cold KALB buffer (150 mM NaCl, $50 \mathrm{mM}$ Tris- $\mathrm{HCl}$ at $\mathrm{pH} 7.5$, $1 \%$ Triton X-100, $1 \mathrm{mM}$ EDTA) supplemented with protease inhibitors (Roche). Lysates containing $60 \mu \mathrm{g}$ of protein were subjected to electrophoresis on a $4 \%-20 \%$ PAGE gel and transferred to membranes (PVDF-Plus, Micron Separation, Inc.). Membranes were preincubated in $10 \%$ skim milk and $0.1 \%$ Tween 20. Membranes were then incubated in $1 \%$ BSA and $0.1 \%$ Tween 20 containing the anti-neo antibody diluted 1:750, washed, then incubated with goat anti-rabbit secondary antibody coupled to horseradish peroxidase (1:3000) before a final washing step. The antibody binding was visualized using chemiluminescence.

\section{Statistical analysis}

SAS StatView 5.0.1 software was used to perform one- or multifactorial analyses of variance followed by Fisher's post-hoc tests as indicated in the figure legends. The default $\alpha$ value of the StatView 5.0.1 software $(5 \%)$ was used.

\section{Acknowledgments}

We thank C. Collin, E. Loza, A. Morcom, S. Mihajlovic, S. Mifsud, and L. Di Rago for expert technical help, and N. Nicola, D. Hilton, W. Alexander, and A. Strasser for critical discussion. This work was supported by The Walter and Eliza Hall Institute of Medical Research and by an Australian NH and MRC project grant.

\section{References}

Anderson, G., Hare, K.J., and Jenkinson, E.J. 1999. Positive selection of thymocytes: The long and winding road. Immunol. Today 20: 463-468.

Berger, S.L. 2002. Histone modifications in transcriptional regulation. Curr. Opin. Genet. Dev. 12: 142-148.

Borrow, J., Stanton, V.J., Andresen, J., Becher, R., Behm, F., Chaganti, R., Civin, C., Disteche, C., Dube, I., Frischauf, A., et al. 1996. The translocation $\mathrm{t}(8 ; 16)(\mathrm{p} 11 ; \mathrm{p} 13)$ of acute myeloid leukaemia fuses a putative acetyltransferase to the CREBbinding protein. Nat. Genet. 14: 33-41.

Carapeti, M., Aguiar, R., Goldman, J., and Cross, N. 1998. A novel fusion between $\mathrm{MOZ}$ and the nuclear receptor coactivator TIF2 in acute myeloid leukemia. Blood 91: 3127-3133. 
Chaffanet, M., Gressin, L., Preudhomme, C., Soenen-Cornu, V., Birnbaum, D., and Pebusque, M.J. 2000. MOZ is fused to p300 in an acute monocytic leukemia with $\mathrm{t}(8 ; 22)$. Genes Chromosomes Cancer 28: 138-144.

Deguchi, K., Ayton, P.M., Carapeti, M., Kutok, J.L., Snyder, C.S., Williams, I.R., Cross, N.C., Glass, C.K., Cleary, M.L., and Gilliland, D.G. 2003. MOZ-TIF2-induced acute myeloid leukemia requires the MOZ nucleosome binding motif and TIF2-mediated recruitment of CBP. Cancer Cell 3: 259-271.

Downing, J.R., Higuchi, M., Lenny, N., and Yeoh, A.E. 2000. Alterations of the AML1 transcription factor in human leukemia. Semin. Cell Dev. Biol. 11: 347-360.

Dzierzak, E. and Medvinsky, A. 1995. Mouse embryonic hematopoiesis. Trends Genet. 11: 359-366.

Ferrara, F.F., Fazi, F., Bianchini, A., Padula, F., Gelmetti, V., Minucci, S., Mancini, M., Pelicci, P.G., Lo Coco, F., and Nervi, C. 2001. Histone deacetylase-targeted treatment restores retinoic acid signaling and differentiation in acute myeloid leukemia. Cancer Res. 61: 2-7.

Gelmetti, V., Zhang, J., Fanelli, M., Minucci, S., Pelicci, P.G., and Lazar, M.A. 1998. Aberrant recruitment of the nuclear receptor corepressor-histone deacetylase complex by the acute myeloid leukemia fusion partner ETO. Mol. Cell. Biol. 18: 7185-7191.

Glass, C.K. and Rosenfeld, M.G. 2000. The coregulator exchange in transcriptional functions of nuclear receptors. Genes \& Dev. 14: 2121-2141.

Grignani, F., De Matteis, S., Nervi, C., Tomassoni, L., Gelmetti, V., Cioce, M., Fanelli, M., Ruthardt, M., Ferrara, F.F., Zamir, I., et al. 1998. Fusion proteins of the retinoic acid receptor- $\alpha$ recruit histone deacetylase in promyelocytic leukaemia. $\mathrm{Na}$ ture 391: 815-818.

Guidez, F., Ivins, S., Zhu, J., Soderstrom, M., Waxman, S., and Zelent, A. 1998. Reduced retinoic acid-sensitivities of nuclear receptor corepressor binding to PML- and PLZFRAR $\alpha$ underlie molecular pathogenesis and treatment of acute promyelocytic leukemia. Blood 91: 2634-2642.

Harrison, D.E., Jordan, C.T., Zhong, R.K., and Astle, C.M. 1993. Primitive hemopoietic stem cells: Direct assay of most productive populations by competitive repopulation with simple binomial, correlation and covariance calculations. Exp. Hematol. 21: 206-219.

Harrison, D.E., Zhong, R.K., Jordan, C.T., Lemischka, I.R., and Astle, C.M. 1997. Relative to adult marrow, fetal liver repopulates nearly five times more effectively long-term than short-term. Exp. Hematol. 25: 293-237.

He, L.Z., Guidez, F., Tribioli, C., Peruzzi, D., Ruthardt, M., Zelent, A., and Pandolfi, P.P. 1998. Distinct interactions of PML-RAR $\alpha$ and PLZF-RAR $\alpha$ with co-repressors determine differential responses to RA in APL. Nat. Genet. 18: 126135.

Huntly, B.J., Shigematsu, H., Deguchi, K., Lee, B.H., Mizuno, S., Duclos, N., Rowan, R., Amaral, S., Curley, D., Williams, I.R., et al. 2004. MOZ-TIF2, but not BCR-ABL, confers properties of leukemic stem cells to committed murine hematopoietic progenitors. Cancer Cell 6: 587-596.

Ichikawa, M., Asai, T., Saito, T., Yamamoto, G., Seo, S., Yamazaki, I., Yamagata, T., Mitani, K., Chiba, S., Hirai, H., et al. 2004. AML-1 is required for megakaryocytic maturation and lymphocytic differentiation, but not for maintenance of hematopoietic stem cells in adult hematopoiesis. Nat. Med. 10: 299-304.

Imamura, T., Kakazu, N., Hibi, S., Morimoto, A., Fukushima, Y., Ijuin, I., Hada, S., Kitabayashi, I., Abe, T., and Imashuku, S. 2003. Rearrangement of the MOZ gene in pediatric therapy-related myelodysplastic syndrome with a novel chromosomal translocation t(2;8)(p23;p11). Genes Chromosomes Cancer 36: 413-419.

Jones, R.J., Wagner, J.E., Celano, P., Zicha, M.S., and Sharkis, S.J. 1990. Separation of pluripotent haematopoietic stem cells from spleen colony-forming cells. Nature 347: 188-189.

Jordan, C.T., Astle, C.M., Zawadzki, J., Mackarehtschian, K., Lemischka, I.R., and Harrison, D.E. 1995. Long-term repopulating abilities of enriched fetal liver stem cells measured by competitive repopulation. Exp. Hematol. 23: 1011-1015.

Kamei, Y., Xu, L., Heinzel, T., Torchia, J., Kurokawa, R., Gloss, B., Lin, S.C., Heyman, R.A., Rose, D.W., Glass, C.K., et al. 1996. A CBP integrator complex mediates transcriptional activation and AP-1 inhibition by nuclear receptors. Cell 85: 403-414.

Kitabayashi, I., Aikawa, Y., Nguyen, L.A., Yokoyama, A., and Ohki, M. 2001a. Activation of AML1-mediated transcription by MOZ and inhibition by the MOZ-CBP fusion protein. EMBO I. 20: 7184-7196.

Kitabayashi, I., Aikawa, Y., Yokoyama, A., Hosoda, F., Nagai, M., Kakazu, N., Abe, T., and Ohki, M. 2001b. Fusion of MOZ and p300 histone acetyltransferases in acute monocytic leukemia with a $\mathrm{t}(8 ; 22)(\mathrm{p} 11 ; \mathrm{q} 13)$ chromosome translocation. Leukemia 15: 89-94.

Kondo, M., Wagers, A.J., Manz, M.G., Prohaska, S.S., Scherer, D.C., Beilhack, G.F., Shizuru, J.A., and Weissman, I.L. 2003. Biology of hematopoietic stem cells and progenitors: Implications for clinical application. Annu. Rev. Immunol. 21: 759-806.

Kung, A.L., Rebel, V.I., Bronson, R.T., Ch'ng, L.E., Sieff, C.A., Livingston, D.M., and Yao, T.P. 2000. Gene dose-dependent control of hematopoiesis and hematologic tumor suppression by CBP. Genes \& Dev. 14: 272-277.

Liang, J., Prouty, L., Williams, B.J., Dayton, M.A., and Blanchard, K.L. 1998. Acute mixed lineage leukemia with an inv(8)(p11q13) resulting in fusion of the genes for MOZ and TIF2. Blood 92: 2118-2122.

Lin, R.J., Nagy, L., Inoue, S., Shao, W., Miller Jr., W.H., and Evans, R.M. 1998. Role of the histone deacetylase complex in acute promyelocytic leukaemia. Nature 391: 811-814.

Lutterbach, B., Westendorf, J.J., Linggi, B., Patten, A., Moniwa, M., Davie, J.R., Huynh, K.D., Bardwell, V.J., Lavinsky, R.M., Rosenfeld, M.G., et al. 1998. ETO, a target of $\mathrm{t}(8 ; 21)$ in acute leukemia, interacts with the N-CoR and $\mathrm{mSin} 3$ corepressors. Mol. Cell. Biol. 18: 7176-7184.

Metcalf, D. 1984. Hemopoietic colony stimulating factors. Elsevier, Amsterdam.

Miller, C.T., Maves, L., and Kimmel, C.B. 2004. Moz regulates Hox expression and pharyngeal segmental identity in zebrafish. Development 131: 2443-2461.

Morrison, S.J., Hemmati, H.D., Wandycz, A.M., and Weissman, I.L. 1995. The purification and characterization of fetal liver hematopoietic stem cells. Proc. Natl. Acad. Sci. 92: 1030210306.

Nutt, S.L., Metcalf, D., D'Amico, A., Polli, M., and Wu, L. 2005. Dynamic regulation of PU.1 expression in multipotent hematopoietic progenitors. J. Exp. Med. 201: 221-231.

Okuda, T., van Deursen, J., Hiebert, S.W., Grosveld, G., and Downing, J.R. 1996. AML1, the target of multiple chromosomal translocations in human leukemia, is essential for normal fetal liver hematopoiesis. Cell 84: 321-330.

Orkin, S.H. 2000. Diversification of haematopoietic stem cells to specific lineages. Nat. Rev. Genet. 1: 57-64.

Purton, J.F., Boyd, R.L., Cole, T.J., and Godfrey, D.I. 2000. Intrathymic $\mathrm{T}$ cell development and selection proceeds normally in the absence of glucocorticoid receptor signalling. Immunity 13: 179-186. 
Thomas et al.

Redner, R.L., Wang, J., and Liu, J.M. 1999. Chromatin remodeling and leukemia: new therapeutic paradigms. Blood 94: 417-428.

Rietze, R.L., Valcanis, H., Brooker, G.F., Thomas, T., Voss, A.K., and Bartlett, P.F. 2001. Purification of a pluripotent neural stem cell from the adult mouse brain. Nature 412: 736-739.

Scheid, M.P. and Triglia, D. 1979. Further description of the Ly-5 system. Immunogenetics 9: 423-433.

Spanopoulou, E., Roman, C.A., Corcoran, L.M., Schlissel, M.S., Silver, D.P., Nemazee, D., Nussenzweig, M.C., Shinton, S.A., Hardy, R.R., and Baltimore, D. 1994. Functional immunoglobulin transgenes guide ordered B-cell differentiation in Rag-1-deficient mice. Genes \& Dev. 8: 1030-1042.

Stark, B., Resnitzky, P., Jeison, M., Luria, D., Blau, O., Avigad, S., Shaft, D., Kodman, Y., Gobuzov, R., Ash, S., et al. 1995. A distinct subtype of M4/M5 acute myeloblastic leukemia (AML) associated with $\mathrm{t}(8: 16)(\mathrm{p} 11: \mathrm{p} 13)$, in a patient with the variant $\mathrm{t}(8: 19)(\mathrm{p} 11: \mathrm{q} 13)$-Case report and review of the literature. Leuk. Res. 19: 367-379.

Strahl, B.D. and Allis, C.D. 2000. The language of covalent histone modifications. Nature 403: 41-45.

Taatjes, D.J., Marr, M.T., and Tjian, R. 2004. Regulatory diversity among metazoan co-activator complexes. Nat. Rev. Mol. Cell Biol. 5: 403-410.

Thomas, T. and Voss, A.K. 2004. Querkopf, a histone acetyltransferase, is essential for embryonic neurogenesis. Front. Biosci. 9: 24-31.

Thomas, T., Voss, A.K., Chowdhury, K., and Gruss, P. 2000. Querkopf, a MYST family histone acetyltransferase, is required for normal cerebral cortex development. Development 127: 2537-2548.

Till, J.E. and McCulloch, E.A. 1961. A direct measurement of the raditation sensitivity of normal mouse bone marrow cells. Radiat. Res. 14: 213.

van der Loo, J.C., van den Bos, C., Baert, M., Wagemaker, G., and Ploemacher, R.E. 1994. Stable multilineage hematopoietic chimerism in $\alpha$-thalassemic mice induced by a bone marrow subpopulation that excludes the majority of day-12 spleen colony-forming units. Blood 83: 1769-1777.

Voss, A.K., Thomas, T., and Gruss, P. 1997. Germ line chimeras from female ES cells. Exp. Cell Res. 230: 45-49.

. 1998. Efficiency assessment of the gene trap approach. Dev. Dyn. 212: 171-180.

Voss, A.K., Gruss, P., and Thomas, T. 2003. The guanine nucleotide exchange factor C3G is necessary for the formation of focal adhesions and vascular maturation. Development 130: 355-367.

Wang, Q., Stacy, T., Binder, M., Marin-Padilla, M., Sharpe, A.H., and Speck, N.A. 1996. Disruption of the Cbfa2 gene causes necrosis and hemorrhaging in the central nervous system and blocks definitive hematopoiesis. Proc. Natl. Acad. Sci. 93: 3444-3449.

Wang, J., Hoshino, T., Redner, R.L., Kajigaya, S., and Liu, J.M. 1998. ETO, fusion partner in $\mathrm{t}(8 ; 21)$ acute myeloid leukemia, represses transcription by interaction with the human N-CoR/mSin3/HDAC1 complex. Proc. Natl. Acad. Sci. 95: 10860-10865.

Yang, X.J. 2004. The diverse superfamily of lysine acetyltransferases and their roles in leukemia and other diseases. Nucleic Acids Res. 32: 959-976.

Yao, T.P., Oh, S.P., Fuchs, M., Zhou, N.D., Ch'ng, L.E., Newsome, D., Bronson, R.T., Li, E., Livingston, D.M., and Eckner, R. 1998. Gene dosage-dependent embryonic development and proliferation defects in mice lacking the transcriptional integrator p300. Cell 93: 361-372.

Zeigler, F.C., Bennett, B.D., Jordan, C.T., Spencer, S.D., Baum- hueter, S., Carroll, K.J., Hooley, J., Bauer, K., and Matthews, W. 1994. Cellular and molecular characterization of the role of the flk-2/flt-3 receptor tyrosine kinase in hematopoietic stem cells. Blood 84: 2422-2430.

Zhu, J. and Emerson, S.G. 2002. Hematopoietic cytokines, transcription factors and lineage commitment. Oncogene 21: 3295-3313. 


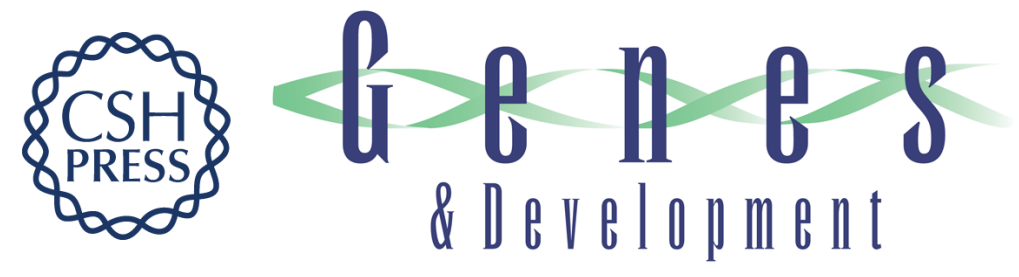

\section{Monocytic leukemia zinc finger protein is essential for the development of long-term reconstituting hematopoietic stem cells}

Tim Thomas, Lynn M. Corcoran, Raffi Gugasyan, et al.

Genes Dev. 2006, 20:

Access the most recent version at doi:10.1101/gad.1382606

Supplemental http://genesdev.cshlp.org/content/suppl/2006/04/17/20.9.1175.DC1
Material

References This article cites 55 articles, 18 of which can be accessed free at:

http://genesdev.cshlp.org/content/20/9/1175.full.html\#ref-list-1

License

Email Alerting Receive free email alerts when new articles cite this article - sign up in the box at the top

Service right corner of the article or click here.

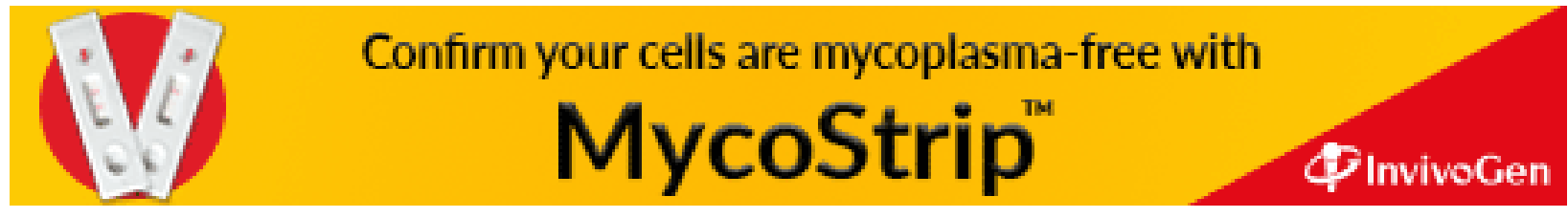

